DOI: 10.2478/awutp-2019-0006

Vol. LXI, 2019

\title{
FABRICATION AND CHARACTERISATION OF ZnO THIN FILM BY SOL-GEL TECHNIQUE
}

\author{
Said Benramache
}

Material Sciences Department, Faculty of Science, University of Biskra 07000, Algeria

*Corresponding author: Email: s.benramache@univ-biskra.dz

\begin{tabular}{|l|l|}
\hline \multicolumn{1}{|c|}{ Article Info } & \multicolumn{1}{c|}{ Abstract } \\
\hline $\begin{array}{l}\text { Received: 17.12.2019 } \\
\text { Accepted: 08.01.2020 }\end{array}$ & $\begin{array}{l}\text { We investigated the structural and optical properties of zinc oxide (ZnO) thin } \\
\text { film as the n-type semiconductor. In this work, the sol-gel method used to fabricate } \\
\text { KnO thin film on glass substrate with 0.5 mol/l of zinc acetate dehydrates. The } \\
\text { film; Sol-Gel technique } \\
\text { crystals quality of the thin film analyzed by X-ray diffraction and the optical } \\
\text { transmittance was carried out by an ultraviolet-visible spectrophotometer. The } \\
\text { DRX analyses indicated that ZnO film have polycrystalline nature and hexagonal } \\
\text { wurtzite structure with (002) preferential orientation and the measured average } \\
\text { crystallite size of ZnO of 207.9 nm. The thin film exhibit average optical } \\
\text { transparency about 90\%, in the visible region, found that optical band gap energy } \\
\text { was 3.282 eV, the Urbach energy also was calculated from optical transmittance to } \\
\text { optimal value is 196.7 meV. }\end{array}$ \\
\hline
\end{tabular}

\section{Introduction}

$\mathrm{ZnO}$ is a very most important semiconductor material due to its applications [1]. It has a direct and wide band gap of $3.3 \mathrm{eV}$ in the near-UV spectral region [2], and a large exciton binding energy $(60 \mathrm{meV})$ at room temperature [3]. It consider that the $\mathrm{ZnO}$ is an n-type semiconducting with high density and good crystalline quality [4], but the use of $\mathrm{ZnO}$ as a semiconductor in electronic devices due to the high transmittance and good electrical conductivity [5]. Therefore, $\mathrm{ZnO}$ thin films are promising candidates for applications in short-wavelength light-emitting devices, lasers, field emission devices, solar cells and sensors [1-6]. Nanocrystalline $\mathrm{ZnO}$ thin films can be produced by several techniques such as reactive evaporation [7], molecular beam epitaxy (MBE), magnetron sputtering technique [8], pulsed laser deposition (PLD) [9], spray pyrolysis [10], sol-gel process [11], chemical vapor deposition, and electrochemical deposition [12].

In this work, $\mathrm{ZnO}$ thin film was deposited on glass substrate by (spin coating) sol-gel method, $\mathrm{ZnO}$ solution was prepared using a zinc acetate dihydrate $\left(\mathrm{Zn}\left(\mathrm{CH}_{3} \mathrm{COO}\right)_{2} \cdot 2 \mathrm{H}_{2} \mathrm{O}\right)$ with precursor molarity of $0.5 \mathrm{~mol}^{-1}{ }^{-1}$. 


\section{Materials and methods}

$\mathrm{ZnO}$ thin film was deposited on glass substrate using a spin coating method, $\mathrm{ZnO}$ solution was prepared by dissolving $0.5 \mathrm{~mol}^{-\mathrm{l}^{-1}}$ of zinc acetate dihydrate $\left(\mathrm{Zn}\left(\mathrm{CH}_{3} \mathrm{COO}\right)_{2} \cdot 2 \mathrm{H}_{2} \mathrm{O}\right)$ in the solvent of absolute methanol solution $\left(\mathrm{CH}_{3} \mathrm{OH}\right)(99.995 \%)$ purity, then have added drops of monoethanolamine solution as a stabilized, the mixture solution was stirred an heated at $50{ }^{\circ} \mathrm{C}$ for $6 \mathrm{~h}$ to yield a clear and transparency solution.

The solution was then spin coated onto the glass substrate, which was rotated at 4000 $\mathrm{r} / \mathrm{min}$ for $50 \mathrm{~s}$. The films were dried in air at $200{ }^{\circ} \mathrm{C}$ for $30 \mathrm{~min}$ on a hot plate. The procedure from coating to drying was repeated 6 times, the final $\mathrm{ZnO}$ thin film as annealed in air at 600 ${ }^{\circ}$ for 2 hours.

Crystallographic and phase structure of the thin film was determined by X-ray diffraction (XRD, Bruker AXS-8D) with $\mathrm{CuK} \alpha$ radiation $(\lambda=0.15406 \mathrm{~nm})$ in the scanning range of $(2 \theta)$ was between $20^{\circ}$ and $55^{\circ}$. The optical transmittance of the deposited film was measured in the range of $300-900 \mathrm{~nm}$ by using ultraviolet-visible spectrophotometer (LAMBDA 25).

\section{Results and Discussions}

The crystal structure of the deposited $\mathrm{ZnO}$ film was studied using X-ray diffraction (XRD). XRD spectra of $\mathrm{ZnO}$ films were showed in Fig. 1. As can be seen, the diffraction peaks were observed at $2 \theta=31.30^{\circ}, 34.50^{\circ}, 36.24^{\circ}$ and $47.30^{\circ}$ which are related to the following plans (100), (002), (101) and (102) respectively (JCPDS File NO.75-0576 from ASTM) [13]. These peaks confirmed that the films are polycrystalline in nature.

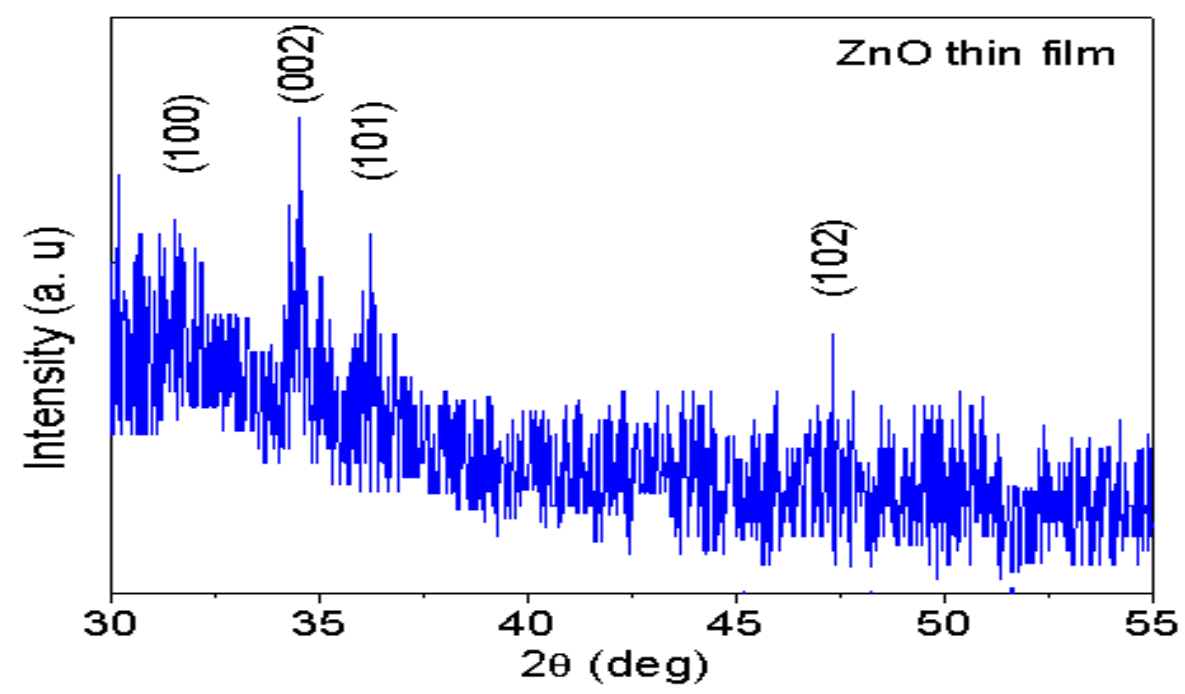

Fig. 1. XRD spectrum of $\mathrm{ZnO}$ thin films prepared using spin coating method. 
The variation of the crystallite size of the $\mathrm{ZnO}$ thin films with substrate temperature was calculated from the four diffraction peaks, using the full width at half maximum (FWHM) in conjunction with the Debye-Scherer formula [3]:

$$
G=\frac{0.9 \lambda}{\beta \cos \theta}
$$

where $G$ is the crystallite size, $\lambda$ is the $\mathrm{X}$-ray wavelength $\left(\lambda=1.5406 \mathrm{~A}^{\circ}\right), \beta$ the full width at half-maximum (FWHM), and $\theta$ is Bragg angle of the diffraction peaks.

The grain size of $\mathrm{ZnO}$ on glass was $207.9 \mathrm{~nm}$, it shows that the grain becomes more uniform and bigger in size on our sample.

According to the hexagonal symmetry, the lattice constant can be calculated by the following formula [14]:

$$
d_{h k l}=\left(\frac{4}{3} \frac{h^{2}+h k+k^{2}}{a^{2}}+\frac{l^{2}}{c^{2}}\right)^{-\frac{1}{2}}
$$

where $a, c$ are the lattice parameters, $(h, k, l)$ are the Miller indices of the planes and $d_{h k l}$ is the interplanar spacing.

The lattice parameters are substrate dependent. This gives rise to a mismatch between the substrate and the deposited thin films. The latter is responsible for the resulting strains and stresses. We estimated the strain $\varepsilon$ values in each thin film deposition via the formula [15]:

$$
\varepsilon=\frac{c-c_{0}}{c_{0}} \times 100 \%
$$

where $\varepsilon$ is the mean strain in $\mathrm{ZnO}$ thin films, $c$ the lattice constant of $\mathrm{ZnO}$ thin films is $0.51952 \mathrm{~nm}$, and $c_{0}$ the lattice constant of bulk (standard $c_{0}=0,5206 \mathrm{~nm}$ ) [13].

The strain was equal to $-0.21 \%$ for the $\mathrm{ZnO}$ thin film deposited on glass substrate. The negative value of the strain in the film means that the sample is in a tensile condition.

Fig. 2, shows the optical transmissions spectra of $\mathrm{ZnO}$ thin film, as it can be seen, a height transparent spectra $T(\lambda)$ with exhibited average optical transparency over $90 \%$, in the visible range. The region of the absorption edge due to the transition between the valence band and the conduction band is located between 360-390 nm, in this region the transmission decreased because of the onset of fundamental absorption. As it was shown in the inset of 
Fig. 2, shows a typical variation of ( $L A)$ vs. photon energy of $\mathrm{ZnO}$ thin film for deducing the Urbach energy, which is related to the disorder in the film network, is expressed as [15]:

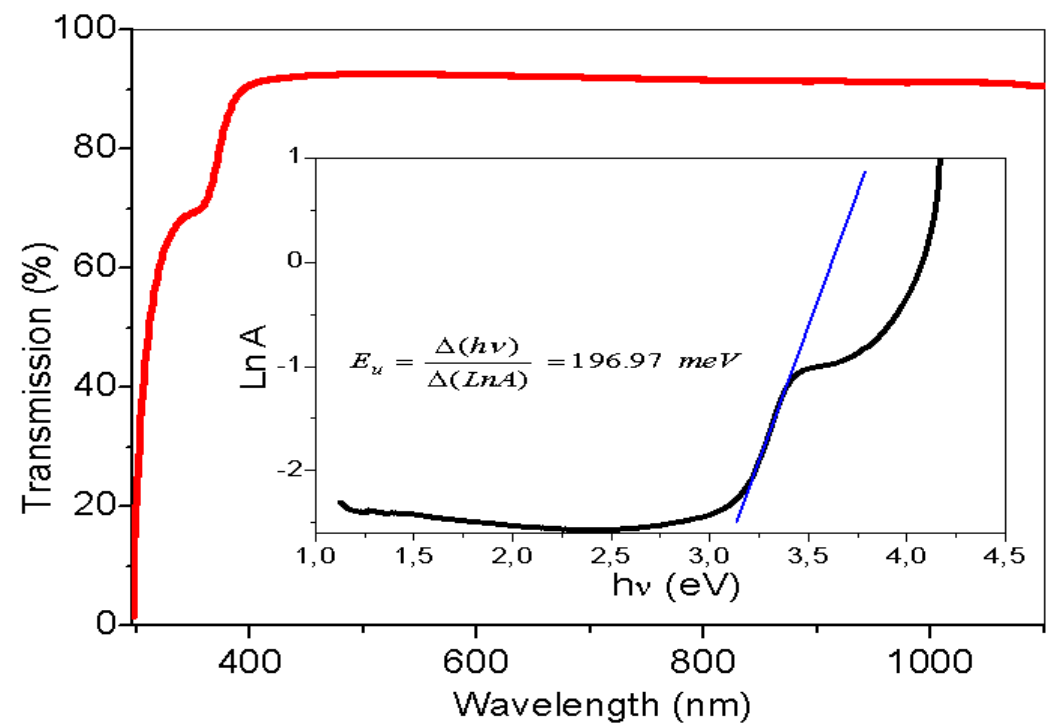

Fig. 2. Transmission spectra $\mathrm{T}(\lambda)$ of $\mathrm{ZnO}$ thin films, the inset of Fig. 2, shows a typical variation of ( $\operatorname{LnA})$ vs.

$$
A=A_{0} \exp \left(\frac{h v}{E_{u}}\right)
$$

where $A_{0}$ is a constant and $E_{u}$ is the Urbach energy was $196.7 \mathrm{meV}$. The optical band gap energy $E_{g}$ was measured from the transmission spectra using the following relations [14]:

$$
(A h v)^{2}=C\left(h v-E_{g}\right)
$$

where $A$ is the absorbance, $C$ is a constant, $h v$ is the photon energy $\left(h v=\frac{1240}{\lambda(n m)}(\mathrm{eV})\right)$ and $E_{g}$ the band gap energy of the semiconductor. As it was shown in (Fig. 3) a typical variation of $(A h v)^{2}$ as a function of photon energy $(h v)$ used for deducing optical band gap $E_{g}$, it is determined by extrapolation of the straight line portion to zero absorption $(A=0)[3]$ the value of $E_{g}$ was $3.282 \mathrm{eV}$. 


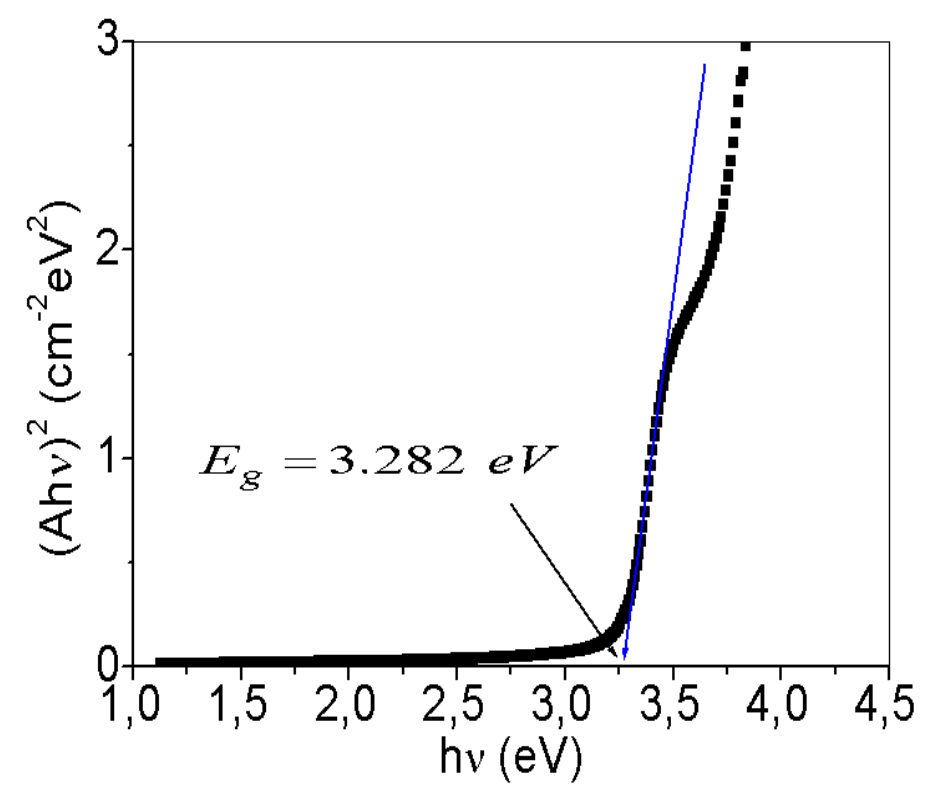

Fig. 3. The typical variation of $(A h v)^{2}$ vs. photon energy of deposited $\mathrm{ZnO}$ thin film.

In this work, Table 1 presents the comparative results of our work with other researches; we have compared the structural, optical and electrical properties of the $\mathrm{ZnO}$ thin films.

Table 1. The comparative study of the structural, optical and electrical properties of ZnO thin films at different conditions.

\begin{tabular}{|c|c|c|c|c|c|c|c|}
\hline $\begin{array}{l}\text { Annealing } \\
\text { temperature } \\
\left({ }^{\circ} \mathrm{C}\right)\end{array}$ & $\begin{array}{l}\text { Deposition } \\
\text { method }\end{array}$ & Phase & $\begin{array}{l}\text { Crystallite } \\
\text { size } G \\
(\mathrm{~nm})\end{array}$ & $\begin{array}{l}\text { Average } \\
\text { transmission } \\
(\%)\end{array}$ & $\begin{array}{l}\text { Optical } \\
\text { energy } \\
E_{g}(\mathrm{eV})\end{array}$ & $\begin{array}{l}\text { Electrical } \\
\text { conductivity } \\
\sigma(\Omega . c \mathrm{~cm})^{-1}\end{array}$ & Rf. \\
\hline 550 & $\begin{array}{c}\text { Sol—gel } \\
\text { Spin Coating }\end{array}$ & $\mathrm{ZnO}$ & 7.01 & 80 & 3.21 & $3.5 .10^{2}$ & [16] \\
\hline 550 & $\begin{array}{c}\text { Sol—gel } \\
\text { Spin Coating }\end{array}$ & $\mathrm{ZnO}+5 \% \mathrm{Cu}$ & 3.21 & 80 & 3.20 & $2.75 .10^{2}$ & [16] \\
\hline $\begin{array}{c}\text { as- } \\
\text { deposited }\end{array}$ & $\begin{array}{c}\text { electron } \\
\text { beam } \\
\text { evaporation }\end{array}$ & $\begin{array}{l}\text { HoF3-doped } \\
\text { ZnO }\end{array}$ & 50 & 85 & 3.26 & 1000 & [17] \\
\hline 400 & $\begin{array}{c}\text { electron } \\
\text { beam } \\
\text { evaporation }\end{array}$ & $\begin{array}{l}\text { HoF3-doped } \\
\text { ZnO }\end{array}$ & 50 & 85 & 3.32 & 45 & [17] \\
\hline 400 & $\begin{array}{c}\mathrm{RF} \\
\text { magnetron } \\
\text { sputtering }\end{array}$ & $\mathrm{ZnO}$ & 57 & 85 & 3.25 & - & [18] \\
\hline 600 & $\begin{array}{c}\text { Sol-gel } \\
\text { Spin Coating }\end{array}$ & $\mathrm{ZnO}$ & 207.9 & 90 & 3.282 & - & $\begin{array}{l}\text { This } \\
\text { work }\end{array}$ \\
\hline
\end{tabular}




\section{Conclusions}

In summary, the high quality $\mathrm{ZnO}$ film on glass substrate was fabricated. The DRX analyses indicated that $\mathrm{ZnO}$ film has polycrystalline nature and hexagonal wurtzite structure with (002) preferential orientation with a high average crystallite size of $207.9 \mathrm{~nm}$. The thin film exhibit average optical transparency about $90 \%$, in the visible region, $\mathrm{ZnO}$ film has optical gap energy of $3.282 \mathrm{eV}$ and the Urbach energy value is $196.7 \mathrm{meV}$.

\section{Acknowledgments}

X-ray diffraction data in this work were acquired with an instrument supported by the University of Biskra. We thank Mr. B. Gasmi (Biskra University) for the assistance in XRD data acquisition.

\section{References}

[1] M.N. Suma, M.V.N. Prasad, V. Gaddam, K. Rajanna, M.M Nayak, Journal of Pure Appliedand Industrial Physics 9(1) (2019) 1-7.

[2] S. Benramache, O. Belahssen, H. Ben Temam, International Journal of Renewable Energy Research 4 (2014) 1009-1012.

[3] S. Benramache, B. Benhaoua, O. Belahssen, Optik 125(2014) 5864-5868.

[4] E.A. Martín-Tovar, R. Castro-Rodríguez, A. Iribarren, Materials Letters 139 (2015) 352354

[5] S. Benramache, Y. Aoun, A. Charef, B. Benhaoua, S. Lakel, Inorganic and Nano-Metal Chemistry 49 (2019) 177-181.

[6] B. Paula, V. Khranovskyy, R. Yakimova, P. Eklund, Materials Research Letters 7 (2019) 239-243.

[7] M. Mekhnache, A. Drici, L.S. Hamideche, Superlattices and Microstructures 49 (2011) $510-518$.

[8] G. Malik, S. Mourya, J. Jaiswal, R. Chandra, Materials Science in Semiconductor Processing 100 (2019) 200-213.

[9] J. Zhoa, L. Hu, W. Wang, W. Liu, A. Gong, Vacuum 82 (2008) 664-667.

[10] S.M. Rozati, Sh. Akesteh, Materials Characterization 58 (2007) 319-322.

[11] J. Ramesha, G. Pasupathi, R. Mariappan, V. Senthil Kumar, V. Ponnuswamy, Optik, 124, (2013) 2023-2027.

[12] C.Y. Zhang, Materials Science in Semiconductor Processing 10 (2007), 215-221.

[13] V. Khomchenko, M. Sopinskyy, M. Mazin, V. Dan'ko, O. Lytvyn,Y. Piryatinskii, 
Journal of Luminescence 213 (2019) 519-524.

[14] A. Rahal, S. Benramache, B. Benhaoua, Engineering Journal 18 (2014) 81-88.

[15] A. Gahtar, S. Benramache, B. Benhaoua, F. Chabane, Journal of Semiconductors, Vol. 34 (2013) 073001-5.

[16] M.F. Attia, Journal of Materials Science Research and Reviews 3 (2) (2019) 1-25.

[17] J.S. Luo, J. Lin, L.G. Zhang, X.Y. Guo, Y.F. Zhu, Chinese Physics Letters 36 (2019) 057303.

[18] S. Guan, L. Hao, M. Murayama, X. Xie, S. Komuro, X. Zhao, IOP Conf. Series: Materials Science and Engineering 522 (2019) 012004. 